\title{
Anti-bacterial effect of Rosmarinus officinalis Linn. extract and Origanum syriacum L. essential oil on survival and growth of total aerobic bacteria and Staphylococcus aureus using cooked chicken meat
}

\author{
Marwan AL-HIJAZEEN ${ }^{1 *}$
}

\begin{abstract}
The effect of oregano essential oil (OE) and rosemary extract (RE) on the survival and growth of Staphylococcus aureus, and the total aerobic bacteria (TA) in cooked ground chicken meat stored at different temperatures had been evaluated. Five treatments including i) Control (no additives); ii) 150 ppm OE; iii) 350 ppm RE; iv) 150 ppm OE + 350 ppm RE; and v) 14 ppm of butylatedhydroxyanisole and butylatedhydroxytolune mixture (BHA/BHT) were prepared. After cooking, all samples were stored ( 7 days) at different temperature $\left(10,25,43^{\circ} \mathrm{C}\right)$ using oxygen permeable bags and tested for TA, and total viable count of Staph. $a$. In addition, all additives were showed significant $(\mathrm{P}<0.05)$ antimicrobial effect during storage time compared to the control. Both OE and RE showed comparable antimicrobial effect compared to the synthetic (BHA/BHT) additive at all storage temperatures. However, the combination treatment $(\mathrm{OE}+\mathrm{RE})$ was the highest among other additives suppress bacterial growth (APC \& Staph. a) during storage. Based on these results, it is concluded that both OE and RE were showed significant $(\mathrm{P}<0.05)$ antimicrobial activity, but this effect could be higher if meat treated by their combined mixture.
\end{abstract}

Keywords: oregano essential oil; rosemary extract; cooked meat; Staphylococcus aureus; storage temperatures.

Practical Application: Combined plants extracts can improve both meat safety, and preventing food borne pathogens (FBPs) which may survive in different meat products.

\section{Introduction}

In developed countries poultry support many poor families through their food and livelihood (Scanes, 2007; Food and Agriculture Organization of the United Nations, 2008, 2020). For those, poultry meats consider one of the cheapest and easily available food protein sources (Food and Agriculture Organization of the United Nations, 2013; Kralik et al., 2017; Marangoni et al., 2015). Therefore, improving preservation technology is required, and highly supports food chain values to achieve better meat quality and safety (Scanes, 2007; Saranraj et al., 2016; Food and Agriculture Organization of the United Nations, 2020). In meat consumption, several food-borne diseases (FBD) may occur and increase the cost of hospitalization, illness, and death even in high income countries such as USA (Centers for Disease Control and Prevention, 2017). The major FBD (over 90\% of food related illness) usually are caused by bacteria, as estimated by CDC-USA center recently. The US-CDC was reported two major group of food borne illnesses: 1) Known food-borne pathogens (FBP) (31 pathogens) and 2) Unspecified agents. However, Staphylococcus aureus consider one of the most important (top five germs) foodborne diseases which may transfer by meat and their products (Kadariya et al., 2014; American Meat Science Association, 2017). For instance, 241,000 illnesses per year caused by Staph. aureus contamination were estimated in the United States, and still consider challenging (Scallan et al., 2011; Al-Hijazeen \& Al-Rawashdeh, 2019). Survival of Staph. aureus strains supressed by achieving optimum cooking and refrigeration temperatures, advanced packaging technology, good manufacturing practices, and perhaps by adding synthetic additives (Dinges et al., 2000; Kadariya et al., 2014; Saranraj et al., 2016). These synthetic additives extend meat shelf life, and improve their quality and safety (Al-Hijazeen, 2019; Al-Hijazeen \& Al-Rawashdeh, 2019). Synthetic antimicrobial/antioxidant additive such as BHA, BHT, and nitrite/nitrate, are widely used in processed meat industry (Sebranek \& Bacus, 2007; Ahn et al., 2007; Kumar et al., 2015; Majou \& Christieans, 2018). However, these synthetic ingredients are questionable, and adversely may affect human health (Oostindjer et al., 2014; Saeed et al., 2019). Now days, researchers interested more in using natural food additives which consider safer alternative (Kumar et al., 2015; Al-Hijazeen, 2019). These plants essential oils and their varieties extracts are well tested, and documented of their positive antimicrobial effect (Kumar et al., 2015; Hintz et al., 2015; Quinto et al., 2019). For instance, oregano, rosemary, sage, thyme, garlic and many medicinal plants and their extracts showed positive antimicrobial effect in both raw and cooked meat products (Hintz et al., 2015; Al-Hijazeen et al., 2016; Kumar et al., 2015; Al-Hijazeen, 2019; Al-Hijazeen \& Al-Rawashdeh, 2019; Quinto et al., 2019). Oregano essential oil (OE) antioxidant/antimicrobial action arising from their polyphenolic constituents: Carvacrol and thymol (78-82\% of its composition), which are responsible on most of their preservation effect (Adam et al., 1998; Yanishlieva et al., 1999). In addition, they are main components of the $\mathrm{OE}$ responsible on 
its antimicrobial activity (Ultee et al., 2002; Nostro et al., 2004, 2007). The antimicrobial activity of OE is well documented, and reported as effective natural antimicrobial for several FBP such as Salmonella typhimurium, Staphylococcus aureus, Vibrio parahaemolyticus, Listeria monocytogenes, and Escherichia coli (Sivropoulou et al., 1996; Ozcan, 2001; Lin et al., 2004; Al-Hijazeen, 2018). In addition, rosemary is very popular and abundant plant grown in Jordan (Middle East), which reported as a powerful antimicrobial food additives (Alzoubi et al., 2014; Al-Hijazeen, 2018; Al-Hijazeen \& Al-Rawashdeh, 2019). The antioxidant/antimicrobial activity of RE linked with their content of phenolic diterpenes such as carnosic acid, carnosol, rosmanol, rosmariquinone and rosmaridiphenol, ursolic acid, and caffeic acid (Aruoma et al., 1992; Basaga et al., 1997; Alzoubi et al., 2014). However, carnosic acid, carnosol, and rosmarinic acid reported as the main bioactive antimicrobial compounds present in RE (Del Campo et al., 2000; Moreno et al., 2006; Jiang et al., 2011; Issabeagloo et al., 2012). Similar to OE, the antimicrobial mechanism of RE is reviewed and explained as: 1) due to their interaction with bacterial cell membrane, which causing alteration in the calls genetic material and nutrients; 2) changing in electrons transportation; 3 ) loss of some cellular composition; 4) loss in membrane functionality (Nieto et al., 2018). The wild oregano and rosemary plants are widely available in Jordan, and their extraction found in a various concentration (Ibrahim et al., 2012a, b; Al-Hijazeen \& Al-Rawashdeh, 2019). Staphylococcus aureus strains may cause FBD due to the effect of their heat stable enterotoxins toxin (Kadariya et al., 2014; Ibrahim et al., 2016). It does not compete well in raw meat, but have more ability to grow and survive on cooked meat (Casman et al., 1963; Normanno et al., 2007). In addition, it ranks the most prevalent causing gastroenteritis problems (Dinges et al., 2000; Hejazi, 2013), food contamination during food preparation, can tolerate salts up to $15 \%$, and can survive in a wide range of temperatures ( 7 to $48.5^{\circ} \mathrm{C}$ ), $\mathrm{pH}$ (4.2 to 9.3), which make Staphylococcus aureus a common FBD (Chaibenjawong \& Foster, 2011; Kadariya et al., 2014). Storage condition and temperature of cooked meat products also very important to decrease their growth and survival specially by cross contamination (Kadariya et al., 2014; Saranraj et al., 2016). In addition, Total Aerobic bacteria (TA) or aerobic plate count (APCs) also can be used to give general indication about bacterial population on the meat samples. TA count evaluates food microbiological status, manufacture system hygiene, quality and food safety (American Public Health Association, 1984) and estimate meat deterioration level (Kim et al., 2018; Saeed et al., 2019). The effect of direct adding essential oils and plants extract are extensively studied, and still need more investigation for a better applied methodology, dose, and best combination which can be consider by food industry (Kumar et al., 2015; Adelakun et al., 2016; Al-Hijazeen \& Al-Rawashdeh, 2019). In addition, no research studies were conducted before to evaluate the combination effect of these plants supplements using cooked chicken meat. Therefore, this research was conducted to investigate: 1 ) effect of Rosmarinus officinalis Linn. extract and Origanum syriacum L. essential oil on survival and growth of TA, and Staphylococcus aureus using cooked chicken meat patties; 2) Comparing this effect with the synthetic antioxidant BHA/BHT currently uses in the meat industry.

\section{Materials and methods}

\subsection{Cooked patties preparation}

Fresh chicken of thigh meat was purchased from a local market and ground twice a through a $8-\mathrm{mm}$ plate then a $3-\mathrm{mm}$ plate (Moulinex, Type DKA1, France). Five treatments were prepared into: 1) Control (no additive);2) $150 \mathrm{ppm} \mathrm{OE;3)} 350 \mathrm{ppm} \mathrm{RE;} \mathrm{4)} \mathrm{Combination} \mathrm{(CM)}$ of $150 \mathrm{ppm} \mathrm{OE}+350 \mathrm{ppm} \mathrm{RE}$; and 5) $14 \mathrm{ppm}$ combination (50\% each) of butylatedhydroxyanisole/ butylatedhydroxytolune (0.02\% of BHA/BHT according to their fat content). Oregano essential oil $(\mathrm{OE})$ and RE dose were selected according to previous meat quality studies which was conducted to evaluate antioxidant effect of plants extracts (Al-Hijazeen \& Al-Rawashdeh, 2019; Al-Hijazeen, 2019). Oregano essential oil (Origanum syriacum L.) was obtained from a certified company in Jordan (Green Fields Factory for oils, Amman/ Jordan) using the most efficient purification, extraction, and steam distillation methods. The additives (OE \& RE) composition analysis was done in the Royal Scientific Society (RSS) research institution in Amman, Jordan. The HPLC analysis of the OE showed that $76.39 \%$ of the essential oil was carvacrol. Rosemary pure extract (Cultivated in Jordan) was obtained from the previous company, and the HPLC analysis of the RE was measured in RSS (Method of Okamura et al., 1994), and it was containing $26 \pm 3 \%$ as the average of phenolic diterpenes ( $4 \%$ carnosol and $6 \%$ carnosic acid and other phenolic compounds). The BHA/BHT powder, RE, and OE were dissolved in $10 \mathrm{~mL}$ of $100 \%$ ethanol, and then mixed with $50 \mathrm{~mL}$ mineral oil (Sant Cruz Biotechnology, Dallas, TX, USA), to prepare their stock working carrier. The ethanol was split out using a rotary evaporator (Heidolph, Model Laborota 4001-effecient) at $\left(70{ }^{\circ} \mathrm{C}, 175 \mathrm{mbar}\right.$ vacuum pressure) before adding the stock to the meat mixture. Each treatment supplement was added to the ground meat, and mixed for $3 \mathrm{~min}$ in a bowl mixer. All treatments were added with the same quantity of mineral oil (carrier) to maintain the same condition. Chicken meat patties (approx. $100 \mathrm{~g}$ each) were individually packaged in separate oxygen-impermeable vacuum bags (Albalabki-Jordan, Malcom SRL, Italy), and were cooked gradually to a maximum temperature $90{ }^{\circ} \mathrm{C}$ using water bath (WNB 14, Memmert, Germany) until the internal temperature of meat samples reach $75^{\circ} \mathrm{C}$. The current research was performed in the Microbiology Laboratory of Agriculture Collage, at Mutah University. Cooked meat samples were placed in a closed cold condition $\left(4.5^{\circ} \mathrm{C}\right)$ and used in experiments within 1-3 hours. All meat packages were removed and replaced by oxygen permeable bags for the inoculation part.

\subsection{Proximate composition, cooking loss percentage, and ultimate $\mathrm{pH}$.}

\section{Proximate analysis}

Chicken thigh meat samples of the five batches were individually sampled to measure their protein, fat, water and ash percentage according to AOAC standard methods (Association of Official Analytical Chemists, 2000).

\section{Cooking loss percentage}

Ground chicken fresh meat samples ( $25 \mathrm{~g}$ ) were prepared as the method described by Al-Hijazeen (2019). 


\section{Ultimate $\mathrm{pH}$ values of raw thigh meat}

The $\mathrm{pH}$ value of raw ground meat samples were determined using a $\mathrm{pH}$ meter (PL-600, pH/mV/Temp Meter, Taiwan) (before cooking) after homogenizing the 1.0-g samples with $9 \mathrm{~mL}$ deionized distilled water (DDW) (Sebranek et al., 2001).

\subsection{Staphylococcus aureus culture preparation}

Four-strains of Staphylococcus aureus were obtained from the culture collection of the Microbial Food Safety Laboratory at Mutah University, and JFDA (Jordan Food and Drug Administration) laboratory. Frozen stocks (in 10\% glycerol at $-80^{\circ} \mathrm{C}$ ) were thawed and cultured separately in tryptic soy broth (TSB; Biolab Zrt. 1141 BUDAPEST Öv u. 43, Hungary) supplemented with $0.6 \%$ yeast extract (TSBYE) at $35^{\circ} \mathrm{C}$ for $24 \mathrm{~h}$. Two consecutive 24 -h transfers of the each culture were prepared in TSBYE $\left(35^{\circ} \mathrm{C}\right)$ to make our working cultures. Before the inoculation part each working culture was individually grown in $10 \mathrm{~mL}$ of TSB supplemented with $0.6 \%$ yeast extract (TSBYEBiolab Zrt. 1141 BUDAPEST Öv u. 43, Hungary) at $35^{\circ} \mathrm{C}$ for $24 \mathrm{~h}$. These strains were adapted gradually in the TSBYE with different concentrations of added Naldixic acid (NA; antibiotic; M.W 232.24, $10 \mathrm{ug} / \mathrm{mL}, 30 \mathrm{ug} / \mathrm{mL}$, and $50 \mathrm{ug} / \mathrm{mL}$; Santa Cruz Biotechnology, Dallas, TX, USA). Two consecutive transfers 24-h for each Naldixic Acid Resistant strain (NAR) cultures were prepared. In addition, when starting, $6 \mathrm{~mL}$ of each individual NAR adapted culture in TSBYE was aseptically transferred to a sterilized centrifuge tube to give a total $24 \mathrm{~mL}$ of strain mixture culture (NARC).

Bacterial cells from current mixture strains were harvested by centrifugation at $10,000 \mathrm{xg}$ for $10 \mathrm{~min}$ at $4{ }^{\circ} \mathrm{C}$ (Medical Centrifuge, TG16G; Hunan Kaida Scientefic Instruments Co., Ltd; China). The pelleted cells were re-suspended in a 24 -mL sterilized saline $(0.85 \% \mathrm{NaCl})$, washed, vortex, and then centrifuged again at the same speed and temperature conditions. After harvesting the cells from the second centrifugation, the collected cells were suspended in fresh saline $(0.85 \% \mathrm{w} / \mathrm{v} \mathrm{NaCl})$ and diluted $(10$ fold) using tubes of saline to obtain $10^{6} \mathrm{CFU} / \mathrm{mL}$ in a suspension of washed cells used for inoculating the ground chicken meat.

\subsection{Preparation and inoculation of meat samples}

Cooked meat samples were prepared (Meat LaboratoryDepartment of Animal Production) and transported to the Microbial Food Safety Laboratory (Dept. of Nutrition and Food Technology) for inoculation and microbial analysis. Meat patties were aseptically transferred to oxygen permeable bags before the inoculation. Each cooked meat patties was inoculated with a mixture of four nalidixic-acid resistant serotypes of Staphylococcus aureus (ATCC 6538, ATCC 25923, ATCC 10390, and ATCC 29213) to give an initial cell concentration of $\sim 10^{4}$ colony forming units $(\mathrm{CFU}) / \mathrm{g}$. All inoculated packages of ground chicken meat were closed, manually smashed and massaged for $40 \mathrm{~s}$ from outside of the bag, and held at different storage times and temperature. At different storage time, samples of cooked meat were analyzed for Staphylococcus aureus survivors. In addition, separate bags of non-inoculated ground cooked meat were stored at 10,25 and $43{ }^{\circ} \mathrm{C}$ and analyzed for aerobic plate counts.

\subsection{Microbial analysis}

Ground chicken patties were aseptically opened from their packages, and two- 25 g portions of meat were transferred into separate sterile filter-lined stomacher bags (Seward $\left.{ }^{\mathrm{Tm}}\right)$. Sterile $0.1 \%(\mathrm{w} / \mathrm{v})$ peptone water $(225 \mathrm{~mL})$ was added to each bag. The meat mixture was homogenized ( 60 second) in a laboratory stomacher blender (Easy Mix, AESAP1068; 35172 BRUZ, France) programmed at medium speed. After that, serial dilutions of meat samples (10-fold) were prepared in sterilized tubes of $0.1 \%$ peptone and $0.1 \mathrm{~mL}$ aliquots of diluted samples were surface plated on appropriate selective agar media to enumerate pathogenic bacteria.

Baird-Parker Agar base were used to enumerate the facultative anaerobic gram positive Staphylococcus aureus. Inoculated agar plates were incubated at $35^{\circ} \mathrm{C}$ and bacterial colonies total count were measured after 48 hours. The aerobic plate count (APC) was determined by surface plating aliquots $(0.1 \mathrm{~mL})$ of meat homogenate on tryptic soy agar (TSA), incubating the inoculated TSA plates at $35^{\circ} \mathrm{C}$, and counting bacterial colonies at 48 hours.

\subsection{Statistical analysis}

Completely randomized design (CRD) was conducted in this study. Two separate samples per treatment per replication were analyzed over 2 replications of each independent experiment. The statistical analysis was performed using the procedures of generalized linear model (Proc. GLM, SAS program, version 9.3, 2012). Mean values and standard error of the means (SEM) were reported. The significance was defined at $\mathrm{P}<0.05$ and Tukey test or Tukey's Multiple Range test were used to determine whether there are significant differences between the mean values.

\section{Results and discussion}

In term of microbiology basis meat composition should be well known when studying the treatments inhibitory effect. In current study, there were no significant differences $(\mathrm{P}>0.05)$ appeared among all treated meat batches of their fat, protein, water, and ash mean percentage (Table 1 ). These results are agreed with Keokamnerd et al. (2008) and Holland et al. (1991) of their proximate analysis using chicken thigh meat. In addition, all treatments samples showed similar cooking loss \% values, and no significant differences $(\mathrm{P}>0.05)$ among them were found when measuring their ultimate $\mathrm{pH}$ values. These data also confirm the univariate, and meat homogenizing starting point (initial count) which makes current study suitable to investigate all supplements antibacterial effect. In present study, storage temperatures of 10 , 25 , and $43^{\circ} \mathrm{C}$ were all used to represent abnormal conditions which allowing aerobic bacteria and Staphylococcus aureus to grow in a poor refrigeration unit $\left(10^{\circ} \mathrm{C}\right)$, during transportation and handling of cooked meat products at ambient temperature $\left(25^{\circ} \mathrm{C}\right)$, and during unsafe $\left(43^{\circ} \mathrm{C}\right)$ hot-holding temperature that may often occur in foodservice area.

Among all treatments samples the APC was increased significantly $(\mathrm{P}<0.05)$ during storage time (Table 2$)$. At $10^{\circ} \mathrm{C}$, all treatments additives were showed significant $(\mathrm{P}<0.05)$ inhibitory (APC) effect after day one of storage time compared to the control samples. Oregano essential oil (OE) was showed 
Table 1. Cooked loss \%, $\mathrm{pA}^{1}$, and $\mathrm{U}-\mathrm{pH}^{2}$ values of chicken thigh of all treatment samples.

\begin{tabular}{|c|c|c|c|c|c|c|}
\hline \multirow{2}{*}{$\mathrm{TRT}^{\star}$} & \multicolumn{4}{|c|}{ Proximate Analysis } & \multirow{2}{*}{ Ash\% } & \multirow{2}{*}{$\mathrm{pH}$ Value } \\
\hline & Cooking Loss $\%$ & Fat $\%$ & Protein \% & Water $\%$ & & \\
\hline Control & $0.171^{\mathrm{a}}$ & $6.87^{\mathrm{a}}$ & $18.74^{\mathrm{a}}$ & $73.43^{\mathrm{a}}$ & $0.96^{\mathrm{a}}$ & $6.17^{\mathrm{a}}$ \\
\hline $\mathrm{OE}$ & $0.178^{\mathrm{a}}$ & $6.85^{\mathrm{a}}$ & $18.45^{\mathrm{a}}$ & $73.72^{\mathrm{a}}$ & $0.97^{\mathrm{a}}$ & $6.16^{\mathrm{a}}$ \\
\hline $\mathrm{RE}$ & $0.176^{\mathrm{a}}$ & $6.87^{\mathrm{a}}$ & $18.45^{\mathrm{a}}$ & $73.74^{\mathrm{a}}$ & $0.94^{\mathrm{a}}$ & $6.11^{\mathrm{a}}$ \\
\hline $\mathrm{CM}$ & $0.177^{\mathrm{a}}$ & $6.71^{\mathrm{a}}$ & $18.60^{\mathrm{a}}$ & $73.73^{\mathrm{a}}$ & $0.96^{\mathrm{a}}$ & $6.16^{\mathrm{a}}$ \\
\hline $\mathrm{BHA} / \mathrm{BHT}$ & $0.173^{\mathrm{a}}$ & $6.94^{\mathrm{a}}$ & $18.48^{\mathrm{a}}$ & $73.61^{\mathrm{a}}$ & $0.97^{\mathrm{a}}$ & $6.14^{\mathrm{a}}$ \\
\hline SEM & 0.011 & 0.073 & 0.078 & 0.085 & 0.04 & 0.065 \\
\hline
\end{tabular}

${ }^{\text {a-e }}$ Different superscripts within a column differ significantly (p<0.05). Treatments: T1) Control; T2) 150 ppm OE; T3) 350 ppm RE; 4) Combination of T2 \& T3; 5) 14 ppm of BHA/BHT. $\mathrm{N}=4$. ${ }^{\mathrm{p}} \mathrm{pA}$ : Proximate analysis of fresh meat before cooking; ${ }^{2} \mathrm{U}-\mathrm{pH}$ : $\mathrm{pH}$ values after $24 \mathrm{~h}$ postmortem of the chicken thigh meat; $\left.{ }^{\star} \mathrm{Treatments:} \mathrm{T} 1\right) \mathrm{Con}$ trol; $\left.\mathrm{T} 2\right) 150 \mathrm{ppm}$ OE; T3) $350 \mathrm{ppm}$ RE; T4) Combination of T2 \& T3: T5) 14 ppm BHA/BHT.

Table 2. Aerobic plate count of cooked chicken (thigh) meat patties during storage at $10{ }^{\circ} \mathrm{C}$.

\begin{tabular}{|c|c|c|c|c|c|}
\hline \multirow{3}{*}{ Treatments } & \multicolumn{4}{|c|}{ Storage (days) } & \multirow{2}{*}{ SEM } \\
\hline & 0 day & 1 day & 3 days & 5 days & \\
\hline & \multicolumn{5}{|c|}{---1 } \\
\hline Control & $2.32^{\mathrm{az}}$ & $4.34^{\text {ay }}$ & $7.51^{\mathrm{ax}}$ & $8.44^{\text {aw }}$ & 0.05 \\
\hline $\mathrm{OE}$ & $2.31^{\mathrm{az}}$ & $4.02^{\text {by }}$ & $5.74^{\text {bx }}$ & $6.37^{\mathrm{bcw}}$ & 0.10 \\
\hline $\mathrm{RE}$ & $2.20^{\mathrm{az}}$ & $4.2^{\text {aby }}$ & $5.99^{\text {bx }}$ & $6.62^{\mathrm{bw}}$ & 0.09 \\
\hline $\mathrm{CM}$ & $2.11^{\mathrm{az}}$ & $3.77^{\mathrm{cy}}$ & $5.55^{\text {bx }}$ & $6.02^{\mathrm{cw}}$ & 0.09 \\
\hline $\mathrm{BHA} / \mathrm{BHT}$ & $2.22^{\mathrm{az}}$ & $4.08^{b y}$ & $5.66^{\text {bx }}$ & $6.20^{\mathrm{cw}}$ & 0.07 \\
\hline SEM & 0.09 & 0.05 & 0.1 & 0.08 & \\
\hline
\end{tabular}

${ }^{a-c}$ Different superscripts within a column differ significantly $(\mathrm{p}<0.05) .{ }^{\mathrm{w}-\mathrm{z}}$ Different superscripts within a row differ significantly $(\mathrm{p}<0.05) . \mathrm{n}=4$. Treatments: T1) Control; T2) 150 ppm OE; T3) 350 ppm RE; T4) Combination of T2 \& T3: T5) 14 ppm BHA/BHT.

higher antibacterial effect (APC test) compared to the RE, but this was not significant $(\mathrm{P}>0.05)$ during storage time. However, the combination of OE \& RE was showed the highest anti-bacterial effect compared to the other treatments additives. Furthermore, no significant differences $(\mathrm{P}>0.05)$ appeared between $\mathrm{OE}, \mathrm{BHA} /$ BHT, and combination treatments at day 5 of their APC at $10^{\circ} \mathrm{C}$. In addition, no synergistic effect was found when adding both $\mathrm{OE} \& \mathrm{RE}$ in combination (Table 2). Generally, bacteria grow faster in all treatments samples during storage when the meat affected by a higher temperature (Table 3 ). The control treatment samples were showed the highest total bacterial count at both storage temperatures of 25 and $43^{\circ} \mathrm{C}$.

In addition, the total number of bacteria (CFU/g meat) was increased significantly $(\mathrm{P}<0.05)$ during the set interval storage time using both temperatures. There were no significant differences $(\mathrm{P}>0.05)$ among all treatments samples at day 0 for all experimental study (Tables 2 and 3 ). The antibacterial effect of both $\mathrm{OE}$ and $\mathrm{RE}$ was very effective during storage time; however their effectiveness was depending on meat storage temperature. For instance, $\mathrm{OE}$ showed better antimicrobial effect at both 10 and $25^{\circ} \mathrm{C}$ storage temperatures. On the other hand, RE antibacterial effect was significantly $(\mathrm{P}<0.05)$ higher using $43^{\circ} \mathrm{C}$ storage temperature during storage time (2-8 hr). It is not clear why RE showed better effect on a higher temperature, but this could be due to their chemical composition, and how these consistent affected and react to each other. Similar results were found in different meat study evaluating the antibacterial effect of OE \& RE either in combination or separately (Ntzimani et al., 2011; Zhang et al., 2016; Nieto et al., 2018; Hać-Szymańczuk et al.,
2019). The highest significant antibacterial effect was showed by the combination treatment (OE \& RE) especially appeared after $6 \mathrm{hr}$ of storage time using both storage temperatures. However, the antibacterial effect of the synthetic BHA/BHT was comparable to the $\mathrm{OE}$ and $\mathrm{RE}$ when it added separately. Furthermore, no synergistic effect was found by the CM treatment, but both RE and $\mathrm{OE}$ showed higher effect compared to their separate effect.

There were no significant differences $(\mathrm{P}>0.05)$ of total viable number regarding Staph .a grown on cooked chicken meat among all treatments additives at day 0 of storage time. However, all treatments additives suppress this pathogen mixture strain (NARC) growth significantly $(\mathrm{P}<0.05)$ compared to the control samples at $10{ }^{\circ} \mathrm{C}$ during storage. In addition, there were no significant differences $(\mathrm{P}>0.05)$ between $\mathrm{RE}$ and $\mathrm{OE}$ treatments of their anti-Staph .a effect until day 5. However, the OE showed higher significant $(\mathrm{P}<0.05)$ anti-Staph activity (7.17 Log CFU/g meat) compared to the RE (7.39 Log CFU/g meat) at day 7 of storage time using temperature of $10^{\circ} \mathrm{C}$ (Table 4 ). In addition, the combination treatment were showed the highest significant $(\mathrm{P}<0.05)$ effect suppress the Staph. a survival and growth compared to the other additives during the storage period (day 5 - day 7). However, the anti-Staph .a effect of synthetic BHA/BHT was similar and comparable to the effect of $\mathrm{OE}$ and $\mathrm{RE}$ when it was adding separately. Researchers reported that adding combinations of natural antimicrobial plant extracts may increase their effectiveness (synergistic effects) ( $\mathrm{Pol} \& \mathrm{Smid}$, 1999; Lin et al., 2004; Brewer., 2011; Abd-Kalek \& Mohamed, 2012). However, in current study the combination of RE and OE dose not expose any synergistic effect against Staph. $a$ and 
Table 3. Aerobic plate counts of cooked meat patties held at 25 or $43^{\circ} \mathrm{C}$ during storage.

\begin{tabular}{|c|c|c|c|c|c|c|}
\hline \multirow{3}{*}{ Treatments } & \multicolumn{6}{|c|}{ Storage (hrs) } \\
\hline & $0 \mathrm{hr}$ & $2 \mathrm{hr}$ & $4 \mathrm{hr}$ & $6 \mathrm{hr}$ & $8 \mathrm{hr}$ & SEM \\
\hline & \multicolumn{6}{|c|}{-------------- Log CFU/g meat ----------- } \\
\hline \multicolumn{7}{|c|}{ Storage at $25^{\circ} \mathrm{C}$} \\
\hline Control & $2.33^{\mathrm{az}}$ & $3.62^{\mathrm{ay}}$ & $4.86^{\mathrm{ax}}$ & $5.60^{\mathrm{aw}}$ & $7.21^{\mathrm{av}}$ & 0.04 \\
\hline $\mathrm{OE}$ & $2.32^{\mathrm{az}}$ & $3.39^{\text {by }}$ & $4.34^{\mathrm{bx}}$ & $5.05^{\mathrm{bcw}}$ & $6.51^{\mathrm{cv}}$ & 0.04 \\
\hline $\mathrm{RE}$ & $2.33^{\mathrm{az}}$ & $3.40^{\text {by }}$ & $4.45^{\text {bx }}$ & $5.35^{\mathrm{abw}}$ & $6.75^{\mathrm{bv}}$ & 0.06 \\
\hline $\mathrm{CM}$ & $2.31^{\mathrm{az}}$ & $2.72^{c y}$ & $3.63^{\mathrm{cx}}$ & $4.22^{\mathrm{dw}}$ & $5.21^{\mathrm{ev}}$ & 0.07 \\
\hline $\mathrm{BHA} / \mathrm{BHT}$ & $2.27^{\mathrm{az}}$ & $2.80^{\text {cy }}$ & $3.85^{\mathrm{cx}}$ & $4.81^{\mathrm{cw}}$ & $5.71^{\mathrm{dv}}$ & 0.05 \\
\hline SEM & 0.03 & 0.04 & 0.04 & 0.09 & 0.04 & \\
\hline \multicolumn{7}{|c|}{ Storage at $43^{\circ} \mathrm{C}$} \\
\hline Control & $2.27^{\mathrm{az}}$ & $3.88^{\text {ay }}$ & $5.11^{\mathrm{ax}}$ & $6.16^{\mathrm{aw}}$ & $8.32^{\mathrm{av}}$ & 0.04 \\
\hline $\mathrm{OE}$ & $2.25^{\mathrm{az}}$ & $3.69^{\text {by }}$ & $4.85^{\text {bx }}$ & $5.82^{\mathrm{bw}}$ & $7.79^{\text {bv }}$ & 0.03 \\
\hline $\mathrm{RE}$ & $2.30^{\mathrm{az}}$ & $2.89^{\text {cy }}$ & $3.67^{\mathrm{dx}}$ & $4.65^{\mathrm{cw}}$ & $6.67^{\mathrm{cv}}$ & 0.04 \\
\hline $\mathrm{CM}$ & $2.20^{\mathrm{az}}$ & $2.68^{c y}$ & $3.48^{\mathrm{ex}}$ & $4.31^{\mathrm{dw}}$ & $6.46^{\mathrm{dv}}$ & 0.02 \\
\hline BHA/BHT & $2.20^{\mathrm{az}}$ & $2.86^{\mathrm{cy}}$ & $3.79^{\mathrm{cx}}$ & $4.67^{\mathrm{cw}}$ & $6.75^{\mathrm{cv}}$ & 0.03 \\
\hline SEM & 0.04 & 0.04 & 0.02 & 0.02 & 0.03 & \\
\hline
\end{tabular}

${ }^{a-e}$ Different superscripts within a column differ significantly $(\mathrm{p}<0.05) .{ }^{\mathrm{x}-\mathrm{e}}$ Different superscripts within a row differ significantly $(\mathrm{p}<0.05) . \mathrm{n}=4$. Treatments: T1) Control; T2) 150 ppm OE; T3) 350 ppm RE; T4) Combination of T2 \& T3: T5) 14 ppm BHA/BHT.

Table 4. Numbers of viable Staphylococcus aureus of cooked chicken meat patties during storage at $10{ }^{\circ} \mathrm{C}$.

\begin{tabular}{|c|c|c|c|c|c|c|}
\hline \multirow{3}{*}{ Treatments } & \multicolumn{6}{|c|}{ Storage (days) } \\
\hline & 0 day & 1 day & 3 days & 5 days & 7 days & SEM \\
\hline & \multicolumn{6}{|c|}{ - Log CFU/g meat - } \\
\hline Control & $4.22^{\mathrm{az}}$ & $5.11^{\text {ay }}$ & $6.58^{\mathrm{ax}}$ & $7.33^{\text {aw }}$ & $8.18^{\mathrm{av}}$ & 0.035 \\
\hline $\mathrm{OE}$ & $4.17^{\mathrm{az}}$ & $4.60^{\text {bcy }}$ & $5.50^{\mathrm{bx}}$ & $6.47^{\mathrm{bcw}}$ & $7.17^{\mathrm{cv}}$ & 0.037 \\
\hline $\mathrm{RE}$ & $4.21^{\mathrm{az}}$ & $4.63^{\text {by }}$ & $5.59^{\mathrm{bx}}$ & $6.65^{\mathrm{bw}}$ & $7.39^{\mathrm{bv}}$ & 0.038 \\
\hline $\mathrm{CM}$ & $4.11^{\text {ay }}$ & $4.22^{\mathrm{dy}}$ & $5.18^{\mathrm{cx}}$ & $5.88^{\mathrm{dw}}$ & $6.50^{\mathrm{dv}}$ & 0.053 \\
\hline BHA/BHT & $4.18^{\mathrm{az}}$ & $4.48^{\text {cy }}$ & $5.26^{\mathrm{cx}}$ & $6.23^{\mathrm{cw}}$ & $7.02^{\mathrm{cv}}$ & 0.062 \\
\hline SEM & 0.06 & 0.03 & 0.02 & 0.06 & 0.05 & \\
\hline
\end{tabular}

${ }^{a-e}$ Different superscripts within a column differ significantly $(\mathrm{P}<0.05) .{ }^{\mathrm{w}-2}$ Different superscripts within a row differ significantly $(\mathrm{P}<0.05) . \mathrm{n}=4$. Treatments: T1) Control; T2) 150 ppm OE; T3)

350 ppm RE; T4) Combination of T2 \& T3: T5) 14 ppm BHA/BHT.

total aerobic bacteria during storage time. Several research studies were reported positive antimicrobial effect, and extend meat shelf-life by using OE in both raw (Al-Hijazeen, 2014; Khaled et al., 2016; Quinto et al., 2019) and cooked/ready to eat meat products (Yemiş \& Candogan, 2017; Ulusoy et al., 2018) against different bacterial strains. For example, the antimicrobial effect of $\mathrm{OE}$ combined with other natural additives against the growth of E. coli O157:H7; Listeria monocytogenes; Salmonella Enteritidis, and Staphylococcus aureus was also reported (Yemiş \& Candogan, 2017; Boskovic et al., 2015; Man et al., 2019). The antimicrobial effect of OE (Origanum syriacum L.) is based on their high carvacrol and other polyphenolic content (Xu et al., 2008; Masadeh et al., 2013; Alhijazeen, 2019). Other researchers (Ultee et al., 1998, 2002; Di Pasqua et al., 2010) reported that $\mathrm{OE}$ and its major component carvacrol changed of bacterial cell membrane potential, and their biological activities inside the cell. The antimicrobial effect of OE (Chouliara et al., 2007; Zhang et al., 2016; Yemiş \& Candogan, 2017) and RE (Kahraman et al., 2015; Al-Hijazeen \& Al-Rawashdeh, 2019) through meat system against several FBP are well documented. In addition, RE and it's essential oil have antimicrobial activity due to their polyphenolic composition (Azizkhani \& Tooryan, 2015; Zhang et al.,
2016). The antimicrobial action of RE explained by its phenolic constituents such as rosmarinic acid, rosmaridiphenol, carnosol, epirosmanol, carnosic acid, rosmanol and isorosmanol as reviewed by Nieto et al. (2018). This positive antimicrobial effect found in current study were connected to the improvement in the meat quality, sensory attributes, color stability reported in previous research studies (Part-I) (Al-Hijazeen \& Al-Rawashdeh, 2019; Al-Hijazeen, 2019). In addition, the antimicrobial effect of this combination (OE \& RE) against survival and growth of Salmonella enterica, Listeria monocytogenes, Escherichia coli O157:H7, Enterobacteriaceae (ENT), and the aerobic plate count (APC) in raw ground chicken meat stored at different temperatures were reported by Al-Hijazeen (2018).

All cooked meat samples were having same initial number (CFU/g meat) of Staph. a count after the inoculation step at $0 \mathrm{hr}$ of storage time (Table 5). This will confirm the univariate concept of having the same total viable number of the Staph. $a$ at the beginning of this study. Staph. $a$ colonies was increased dramatically, and very fast compared to the previous experiments which were used lower storage temperatures. For both storage temperatures $\left(25\right.$ and $\left.43^{\circ} \mathrm{C}\right) \mathrm{OE}$ was showed higher anti-Staph effect compared to the RE during storage time. The effect of all 
Table 5. Numbers of viable Staphylococcus aureus in cooked ground meat patties held at 25 or $43^{\circ} \mathrm{C}$.

\begin{tabular}{|c|c|c|c|c|c|c|}
\hline \multirow{3}{*}{ Treatments } & \multicolumn{6}{|c|}{ Storage (hrs) } \\
\hline & $0 \mathrm{hr}$ & $2 \mathrm{hr}$ & $4 \mathrm{hr}$ & $6 \mathrm{hr}$ & $8 \mathrm{hr}$ & SEM \\
\hline & \multicolumn{6}{|c|}{ 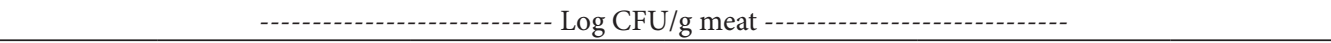 } \\
\hline \multicolumn{7}{|c|}{ Storage at $25^{\circ} \mathrm{C}$} \\
\hline Control & $4.22^{\mathrm{az}}$ & $4.76^{\text {ay }}$ & $5.45^{\mathrm{ax}}$ & $5.81^{\mathrm{aw}}$ & $6.59^{\mathrm{av}}$ & 0.029 \\
\hline $\mathrm{OE}$ & $4.22^{\mathrm{az}}$ & $4.52^{\text {cy }}$ & $4.82^{\mathrm{bx}}$ & $5.26^{\mathrm{cw}}$ & $5.63^{\text {bv }}$ & 0.022 \\
\hline $\mathrm{RE}$ & $4.29^{\mathrm{az}}$ & $4.61^{\text {by }}$ & $4.97^{\mathrm{bx}}$ & $5.45^{\mathrm{bw}}$ & $5.70^{\mathrm{bv}}$ & 0.051 \\
\hline $\mathrm{CM}$ & $4.19^{\mathrm{az}}$ & $4.39^{\mathrm{dy}}$ & $4.56^{\mathrm{cx}}$ & $4.88^{\mathrm{dw}}$ & $5.20^{\mathrm{dv}}$ & 0.038 \\
\hline BHA/BHT & $4.24^{\mathrm{az}}$ & $4.44^{\text {cdy }}$ & $4.63^{c x}$ & $5.01^{\mathrm{dw}}$ & $5.43^{\mathrm{cv}}$ & 0.028 \\
\hline SEM & 0.045 & 0.021 & 0.036 & 0.039 & 0.029 & \\
\hline \multicolumn{7}{|c|}{ Storage at $43^{\circ} \mathrm{C}$} \\
\hline Control & $4.24^{\mathrm{az}}$ & $5.44^{\text {ay }}$ & $6.62^{\mathrm{ax}}$ & $7.74^{\mathrm{aw}}$ & $8.55^{\mathrm{av}}$ & 0.036 \\
\hline $\mathrm{OE}$ & $4.21^{\mathrm{az}}$ & $4.71^{\text {bcy }}$ & $5.73^{c x}$ & $6.77^{\mathrm{bw}}$ & $7.34^{\mathrm{bv}}$ & 0.028 \\
\hline $\mathrm{RE}$ & $4.19^{\mathrm{az}}$ & $4.82^{\text {by }}$ & $5.88^{\mathrm{bx}}$ & $6.88^{\mathrm{bw}}$ & $7.53^{\text {bv }}$ & 0.035 \\
\hline $\mathrm{CM}$ & $4.21^{\mathrm{ay}}$ & $4.55^{\mathrm{dy}}$ & $5.29^{\mathrm{ex}}$ & $6.22^{\mathrm{dw}}$ & $7.16^{\mathrm{bv}}$ & 0.110 \\
\hline BHA/BHT & $4.23^{\mathrm{az}}$ & $4.64^{\text {cdy }}$ & $5.43^{\mathrm{dx}}$ & $6.47^{\mathrm{cw}}$ & $7.20^{\text {bv }}$ & 0.023 \\
\hline SEM & 0.051 & 0.026 & 0.024 & 0.033 & 0.11 & \\
\hline
\end{tabular}

${ }^{a-e}$ Different superscripts within a column are differ significantly $(\mathrm{p}<0.05) .{ }^{\mathrm{x}-\mathrm{z}}$ Different superscripts within a row are differ significantly $(\mathrm{p}<0.05) . \mathrm{n}=4$. Treatments: T1) Control; T2) 150 ppm OE; T3) 350 ppm RE; T4) Combination of T2 \& T3: T5) 14 ppm BHA/BHT.

treatments additives was very comparable, especially at $43^{\circ} \mathrm{C}$ to each other. However, the CM treatment was always had the lower viable numbers compared to the other treatments additives for both storage temperatures $\left(25\right.$ and $\left.43^{\circ} \mathrm{C}\right)$. The effect of RE and $\mathrm{OE}$ was higher than using them individually during storage time (Table 5). No synergistic effect was found in current study between both OE and RE. This possible synergistic activity between the RE and other natural antioxidants may not achieve in some cases (Nieto et al., 2018).

The inhibitory effect of RE incorporated into different meat system against E. coli, Bacillus cereus, Staphylococcus aureus, Clostridium perfringens, Bacillus cereus, Brochothrix thermosph -acta, and Enterobacteriaceae is well documented (Pandit \& Shelef, 1994; Burt, 2004; Ahn et al., 2007; Sirocchi et al., 2013). In addition, $\mathrm{OE}$ and their extract inhibitory effect was already discussed, and their antibacterial effect against several FBP through varieties of meat mixture preparation is also reported (Chouliara et al., 2007; Boskovic et al., 2015; Khaled et al., 2016; Man et al., 2019). Similar results were found by Al-Hijazeen (2014) who reported that OE (Origanuim vulgare subsp. hirtum) at level 200 ppm showed a potential antimicrobial activity in both raw and cooked chicken meat. Finally, in order to achieve this effect in the practical meat industry these findings still need more investigation. For instance, method of adding, dose, products composition, carrier type, and their interaction with meat mixture of each individual product always needs evaluation.

\section{Conclusion}

All additives were showed significant $(\mathrm{P}<0.05)$ antimicrobial activity during storage time against both Staph. $a$ and aerobic bacteria. Both OE (150 ppm) \& RE (350 ppm) were suppress bacterial growth and survival at all storage temperatures $\left(10,25,43^{\circ} \mathrm{C}\right)$. However, it is clearly appeared that combination $(\mathrm{OE}+\mathrm{RE})$ treatment effect is better than using them alone. Overall, their antibacterial activities may consider effective as the synthetic antimicrobial (BHA/BHT); however no synergistic effect appeared by using them in combination. The combination of these two plants extract gives more hope to use them in the future of processed meat, and their products. Finally, it is still need more investigation to use this substation in the meat industry such as mixing method, level, and effectiveness after processing, their effect on other food-brone pathogens.

\section{Acknowledgements}

This study was financially supported by the Deanship of Scientific Research at Mutah University, Al-karak, Jordan (Grant number: 120/14/118). This funding is highly appreciated with my deep thankful to all other Animal Science Department faculty and stuff on their help and advices.

\section{References}

Abd-Kalek, H., \& Mohamed, E. (2012). Synergistic effect of certain medicinal plants and amoxicillin against some clinical isolates of methicillin-resistant Staphylococcus Aureus (MRSA). International Journal of Pharmaceutical Applications, 3(3), 387-398. Retrieved from http://www.bipublication.com/

Adam, K., Sivropoulou, A., Kokkini, S., Lanaras, T., \& Arsenakis, M. (1998). Antifungal activities of Origanum vulgare subsp. hirtum, Mentha spicata, Lavandula angustifolia, and Salvia fruticosa essential oils against human pathogenic fungi. Journal of Agricultural and Food Chemistry, 46(5), 1739-1745. http://dx.doi.org/10.1021/jf9708296.

Adelakun, O. E., Oyelade, O. J., \& Olanipekun, B. F. (2016). Use of essential oils in food preservation. In V. R. Preedy (Ed.), Essential oils in food preservation, flavor and safety (Chap. 7, pp. 71-84). Amsterdam: Elsevier. http://dx.doi.org/10.1016/B978-0-12-416641-7.00007-9.

Ahn, J., Grün, I. U., \& Mustapha, A. (2007). Effects of plant extracts on microbial growth, color change and lipid oxidation in cooked beef. Food Microbiology, 24(1), 7-14. http://dx.doi.org/10.1016/j. fm.2006.04.006. 
Al-Hijazeen, M. (2014). Effect of oregano essential oil and tannic acid on storage stability and quality of ground chicken meat (Graduate Theses and Dissertations). Iowa State University, Iowa.

Al-Hijazeen, M. (2018). Evaluate anti-bacterial activity of Rosmarinus officinalis Linn. extract and Origanum syriacum L. essential oil using raw chicken meat. Carpathian Journal of Food Science and Technology, 10(2), 132-145.

Al-Hijazeen, M. (2019). Effect of Origanuim syriacum L. essential oil on the storage stability of cooked chicken meat. Brazilian Journal of Poultry Science, 21(1), 1-10. http://dx.doi.org/10.1590/18069061-2017-0719.

Al-Hijazeen, M., \& Al-Rawashdeh, M. (2019). Preservative effects of rosemary extract (Rosmarinus officinalis L.) on quality and storage stability of chicken meat patties. Food Science and Technology, 39(1), 27-34. http://dx.doi.org/10.1590/1678-457x.24817.

Al-Hijazeen, M., Lee, E. J., Mendonca, A., \& Ahn, D. U. (2016). Effect of oregano essential oil (Origanum vulgare subsp. Hirtum) on the storage stability and quality parameters of ground chicken breast meat. Antioxidants, 5(2), 18. http://dx.doi.org/10.3390/antiox5020018.

Alzoubi, H. M., Ibrahim, A. I., Alsbou, M. S., \& Aqel, A. A. (2014). Inhibitory effect of Mediterranean sage and rosemary on clinical and community isolates of methicillin-resistant Staphylococcus aureus. Jordan Journal of Biological Sciences, 7(3), 161-164. http:// dx.doi.org/10.12816/0008233.

American Meat Science Association - AMSA. (2017). What foodborne organisms are associated with meat and poultry? (No. 12). Missouri: AMSA. Retrieved from www.meatscience.org/TheMeatWeEat/ Topicis/MeatSafety/Article

American Public Health Association - APHA. (1984). Compendium of methods for the microbiological examination of foods (2nd ed.). Washington: APHA.

Aruoma, O. I., Halliwell, B., Aeschbach, R., \& Löligers, J. (1992). Antioxidant and pro-oxidant properties of active rosemary constituents: carnosol and carnosic acid. Xenobiotica, 22(2), 257-268. http:// dx.doi.org/10.3109/00498259209046624.

Association of Official Analytical Chemists - AOAC. (2000). Official methods of analysis (16th ed.). Gaithersburg: AOAC.

Azizkhani, M., \& Tooryan, F. (2015). Antioxidant and Antimicrobial activities of rosemary extract, mint extract and a mixture of tocopherols in beef sausage during storage at $4{ }^{\circ} \mathrm{C}$. Journal of Food Safety, 35(1), 128-136. http://dx.doi.org/10.1111/jfs.12166.

Basaga, H., Tekkaya, C., \& Acikel, F. (1997). Antioxidative and free radical scavenging properties of rosemary extract. LebensmittelWissenschaft + Technologie, 30(1), 105-108. http://dx.doi.org/10.1006/ fstl.1996.0127.

Boskovic, M., Zdravkovic, N., Ivanovic, J., Janjic, J., Djordjevic, J., Starcevic, M., \& Baltic, M. Z. (2015). Antimicrobial activity of thyme (Tymus vulgaris) and oregano (Origanum vulgare) essential oils against some food-borne microorganisms. Procedia Food Science, 5, 18-21. http://dx.doi.org/10.1016/j.profoo.2015.09.005.

Brewer, M. S. (2011). Natural antioxidant: Sources, compounds, mechanisms of action, and potential applications. Comprehensive Reviews in Food Science and Food Safety, 10(4), 221-247. http:// dx.doi.org/10.1111/j.1541-4337.2011.00156.x.

Burt, S. (2004). Essential oils: Their antibacterial properties and potential applications in foods: a review. International Journal of Food Microbiology, 94(3), 223-253. http://dx.doi.org/10.1016/j. ijfoodmicro.2004.03.022.
Casman, E. P., McCoy, D. W., \& Brandly, P. J. (1963). Staphylococcal growth and enterotoxin production in meat. Applied Microbiology, 11(6), 498-500. http://dx.doi.org/10.1128/AM.11.6.498-500.1963.

Centers for Disease Control and Prevention - CDC. (2017). Estimates offoodborne illness in the United States. Atlanta: National Center for Emerging and Zoonotic Infectious Diseases (NCEZID), Division of Foodborne, Waterborne, and Enviromental Diseases (DFWED). U.S. Department of Health \& Human Services HHS/Open. Retrieved from http://cdc.gov/food borneburden/index.html

Chaibenjawong, P., \& Foster, S. J. (2011). Desiccation tolerance in Staphylococcus aureus. Archives of Microbiology, 193(2), 125-135. http://dx.doi.org/10.1007/s00203-010-0653-x.

Chouliara, E., Karatapanis, A., Savvaidis, I. N., \& Kontominas, M. G. (2007). Combined effect of oregano essential oil and modified atmosphere packaging on shelf-life extension of fresh chicken breast meat, stored at $4{ }^{\circ} \mathrm{C}$. Food Microbiology, 24(6), 607-617. http://dx.doi. org/10.1016/j.fm.2006.12.005.

Del Campo, J., Amiot, M. J., \& Nguyen-The, C. (2000). Antimicrobial effect of rosemary extracts. Journal of Food Protection, 63(10), 1359-1368. http://dx.doi.org/10.4315/0362-028X-63.10.1359. PMid:11041135.

Di Pasqua, R., Mamone, G., Ferranti, P., Ercolini, D., \& Mauriello, G. (2010). Changes in the proteome of Salmonella enterica serovar Thompson as stress adaptation to sublethal concentrations of thymol. Proteomics, 10(5), 1040-1049. http://dx.doi.org/10.1002/ pmic.200900568. PMid:20049861.

Dinges, M. M., Orwin, P. M., \& Schlievert, P. M. (2000). Enterotoxins of Staphylococcus aureus. Clinical Microbiology Reviews, 13(1), 16-34. http://dx.doi.org/10.1128/CMR.13.1.16.

Food and Agriculture Organization of the United Nations - FAO. (2008). Poultry sector country review: based on poultry sector analysis: structure and market and importance of commercial poultry production in Jordan, for a better understanding of Avian influenza challenges. Rome: FAO. Retrieved from www.fao.org/avianflu /en/ farmingsystems.html

Food and Agriculture Organization of the United Nations - FAO. (2013). The role of poultry in human nutrition: poultry development review (pp. 1-119). Rome: FAO. Retrieved from http://www.fao. org/3/i3531e/i3531e02.pdf

Food and Agriculture Organization of the United Nations - FAO. (2020). Preservation and processing technologies to improve availability and safety of meat and meat products in developing countries. Rome: FAO. Retrieved from http://www.fao.org/3/v810t/v8180T11.htm

Hać-Szymańczuk, E., Cegielka, A., Karkos, M., Gniewosz, M., \& Piwowarek, K. (2019). Evaluation of antioxidant and antimicrobial activity of oregano (Origanum vulgare L.) preparations during storage of low-pressure mechanically separated meat (BAADER meat) from chicken. Food Science and Biotechnology, 28(2), 449-457. http:// dx.doi.org/10.1007/s10068-018-0491-1.

Hejazi, M. A. (2013). Microbial changes in cattle carcasses stored at chilling condition (Master's thesis). Faculty of Veterinary Medicine, Alexandria University, Alexandria, Egypt.

Hintz, T., Matthews, K. K., \& Di, R. (2015). The use of plant antimicrobial compounds for food preservation. BioMed Research International, 2015, 246264. http://dx.doi.org/10.1155/2015/246264.

Holland, B., Welch, A. A., Unwin, I. D., Buss, D. H., Paul, A. A., \& Southgate, D. A. T. (1991). McCance \& Widdowson's the composition offood: fifth revised and extended edition (p. 152). Cambridge: Royal Society of Chemistry.

Ibrahim, H., El Sabagh, R., Abou El-Roos, N., \& Abd El Fattah, H. (2016). Antimicrobial effect of some essential oils on Staphylococcus 
aureus in minced meat. Benha Veterinary Medical Journal, 30(1), 183-191. http://dx.doi.org/10.21608/bvmj.2016.31362.

Ibrahim, R. W., Haddad, N., Haddadin, M., \& Abu-Salah, K. (2012a). Evaluation of agro-morphological characters and oil percentage of Origanum syriacum L. at three dates of initial cutting. Jordan Journal of Agricultural Sciences, 8(1), 33-44. Retrieved from https://journals. ju.edu.jo/JJAS/article/view/2930

Ibrahim, R. W., Haddad, N., Haddadin, M., Abu-Salah, K., \& Amri, A. (2012b). Diversity among and within wild populations of Origanum syriacum collected from Jordan. Crop Research, 43(1-3), 249-259.

Issabeagloo, E., Kermanizadeh, P., Taghhizadieh, M., \& Froughi, R. (2012). Antimicrobial effects of rosemary (Rosemarinus officinalis L.) essential oils against staphylococcus spp. African Journal of Microbiological Research, 6(23), 5039-5042. http://dx.doi.org/10.5897 /AJMR12.741.

Jiang, Y., Wu, N., Fu, Y.-J., Wang, W., Luo, M., Zhao, C.-J., Zu, Y.-G., \& Liu, X.-L. (2011). Chemical composition and antimicrobial activity of the essential oil of rosemary. Environmental Toxicology and Pharmacology, 32(1), 63-68. http://dx.doi.org/10.1016/j. etap.2011.03.011.

Kadariya, J., Smith, T. C., \& Thapaliya, D. (2014). Staphylococcus aureus and Staphylococcal Food-Borne disease: an ongoing challenge in public health. BioMed Research International, 2014, 827965. http:// dx.doi.org/10.1155/2014/827965. PMid:24804250.

Kahraman, T., Issa, G., Bingol, E. B., Kahraman, B. B., \& Dumen, E. (2015). Effect of rosemary essential oil and modified-atmosphere packaging (MAP) on meat quality and survival of pathogens in poultry fillets. Brazilian Journal of Microbiology, 46(2), 591-599. http://dx.doi.org/10.1590/S1517-838246220131201.

Keokamnerd, T., Acton, J. C., Han, I. Y., \& Dawson, P. (2008). Effect of commercial rosemary oleoresin preparations on ground chicken thigh meat quality packaged in a high-oxygen atmosphere. Poultry Science, 87(1), 170-179. http://dx.doi.org/10.3382/ps.2007-00066.

Khaled, H., Aziziah, A., \& Marii, A. (2016). Effect of oregano extract on shelf-life, microbiological quality of chilled chicken carcasses. International Food Research Journal, 23(3), 1296-1299. Retrieved from http://www.ifrj.upm.edu.my

Kim, H.-J., Kim, D., Kim, H.-J., Song, S.-O., Song, Y.-H., \& Jang, A. (2018). Evaluation of the microbiological status of raw beef in Korea: considering the suitability of aerobic plate count guidelines. Korean Journal for Food Science of Animal Resources, 38(1), 43-51. PMid:29725223.

Kralik, G., Kralik, Z., Grcevic, M., \& Hanzek, D. (2017). Quality of chicken meat. In B. Yucel \& T. Taskin (Eds.), Animal husbandry and nutrition. London: IntechOpen. Retrieved from http://www. intec hopen.com/books/animal-husbandry-and-nutrition/ qualityof-chicken-meat

Kumar, Y., Yadav, D. N., Ahmad, T., \& Narsaiah, K. (2015). Recent trend in the use of natural antioxidants for meat and meat products. Comprehensive Reviews in Food Science and Food Safety, 14(6), 796812. http://dx.doi.org/10.1111/1541-4337.12156.

Lin, Y. T., Labbe, R. G., \& Shetty, K. (2004). Inhibition of Listeria monocytogenes in fish and meat system by use of oregano and cranberry phytochemical synergies. Applied and Environmental Microbiology, 70(9), 5672-5678. http://dx.doi.org/10.1128/ AEM.70.9.5672-5678.2004. PMid:15345457.

Majou, D., \& Christieans, S. (2018). Mechanisms of the bactericidal effects of nitrate and nitrite in cured meats. Meat Science, 145, 273 284. http://dx.doi.org/10.1016/j.meatsci.2018.06.013. PMid:30005374.
Man, A., Santacroce, L., Iacob, R., Mare, A., \& Man, L. (2019). Antimicrobial activity of six essential oils against a group of human pathogens: a comparative study. Pathogens, 8(1), 15. http://dx.doi. org/10.3390/pathogens8010015. [MDPI]

Marangoni, F., Corsello, G., Cricelli, C., Ferrara, N., Ghiselli, A., Lucchin, L., \& Poli, A. (2015). Role of poultry meat in a balanced diet aimed at maintaining health and wellbeing: an Italian consensus document. Food \& Nutrition Research, 59(1), 27606. http://dx.doi.org/10.3402/ fnr.v59.27606. PMid:26065493.

Masadeh, M. M., Alkofahi, A. S., Tumah, H. N., Mhaidat, N. M., \& Alzoubi, K. H. (2013). Antibacterial activity of some medicinal plants grown in Jordan. Pakistan Journal of Pharmaceutical Sciences, 26(2), 267-270. PMid:23455195.

Moreno, S., Scheyer, T., Romano, C. S., \& Vojnov, A. A. (2006). Antioxidant and antimicrobial activities of rosemary extract linked to their polyphenol composition. Free Radical Research, 40(2), 223231. http://dx.doi.org/10.1080/10715760500473834.

Nieto, G., Ros, G., \& Castillo, J. (2018). Antioxidant and antimicrobial properties of rosemary (Rosmarinus officinalis, L.): review. Medicines, 5(3), 98. http://dx.doi.org/10.3390/medicines5030098. PMid:30181448.

Normanno, G., LaSalandra, G., Dambrosio, A., Quaglia, N. C., Corrente, M., Parisi, A., Santagada, G., Firinu, A., Crisetti, E., \& Celano, G. V. (2007). Occurrence, characterization and antimicrobial resistance of enterotoxigenic Stapylococcus aureus isolated from meat and dairy products. International Journal of Food Microbiology, 115(3), 290296. http://dx.doi.org/10.1016/j.ijfoodmicro.2006.10.049.

Nostro, A., Blanco, A. R., Cannatelli, M. A., Enea, V., Flamini, G., Morelli, I., Sudano Roccaro, A., \& Alonzo, V. (2004). Susceptibility of methicillin-resistant staphylococci to oregano essential oil, carvacrol and thymol. FEMS Microbiology Letters, 230(2), 191-195. http://dx.doi.org/10.1016/S0378-1097(03)00890-5. PMid:14757239.

Nostro, A., Roccaro, A. S., Bisignano, G., Marino, A., Cannatelli, M. A., Pizzimenti, F. C., Cioni, P. L., Procopio, F., \& Blanco, A. R. (2007). Effect of oregano, carvacrol and thymol on Staphylococcus aurus and Staphylococcus epidermidis biofilms. Journal of Medical Microbiology, 56(4), 519-523. http://dx.doi.org/10.1099/jmm.0.46804-0.

Ntzimani, A. G., Giatrakou, V. I., \& Savvaidis, I. N. (2011). Combined natural antimicrobial treatments on a ready-to-eat poultry product stored at 4 and $8{ }^{\circ} \mathrm{C}$. Poultry Science, 90(4), 880-888. http://dx.doi. org/10.3382/ps.2010-00816.

Okamura, N., Fujimoto, Y., Kuwabara, S., \& Yagi, A. (1994). High performance liquid chromatographic determination of carnosic acid and carnosol in Rosmarinus officinalis and salvia officinalis. Journal of Chromotagraphy A, 679(2), 381-386. http://dx.doi. org/10.1016/0021-9673(94)80582-2.

Oostindjer, M., Alexander, J., Amdam, G. V., Anderson, G., Bryan, N. S., Chen, D., Corpet, D. E., Smet, S. D., Dragsted, L. O., Haug, A., Karlsson, A. H., Ketler, G., Kok, T. M., Kulseng, B., Milkowski, A. L., Martin, R. J., Pajari, A. M., Paulsen, J. E., Pickova, J., Rudi, K., Sodring, M., Weed, D. L., \& Egelandsdal, B. (2014). The role of red and processed meat in colorectal cancer development: a perspective. Meat Science, 97(4), 583-596. http://dx.doi.org/10.1016/j. meatsci.2014.02.011. PMid:24769880.

Ozcan, M. (2001). Antimicrobial activity of the essential oil of Turkish plant spices. European Food Research and Technology, 212(6), 658660. http://dx.doi.org/10.1007/s002170100310.

Pandit, V. A., \& Shelef, L. A. (1994). Sensitivity of Listeria monocytogenes to rosemary (Rosmarinus officinalis L.). Food Microbiology, 11(1), 57-63. http://dx.doi.org/10.1006/fmic.1994.1008.

Pol, I. E., \& Smid, E. J. (1999). Combined action of nisin and carvacrol on Bacillus cereus and Listeria monocytogenes. Letters in Applied 
Microbiology, 29(3), 166-170. http://dx.doi.org/10.1046/j.13652672.1999.00606.x.

Quinto, E. J., Caro, I., Villalobos-Delgado, L. H., Mateo, J., De-MateoSilleras, B., \& Redondo-Del-Rio, M. P. (2019). Food safety through natural antimicrobials. Antibiotics, 8(4), 208. http://dx.doi.org/10.3390/ antibiotics 8040208 .

Saeed, F., Afzaal, M., \& Ahmad, A. (2019). Use of natural antimicrobial agent: a safe preservative approach. In I. Var \& S. Uzunlu (Eds.), Active antimicrobial food packaging. London: IntechOpen. Retrieved from https://www.intechopen. com/booksactive-antimicrobialfood-packaging/use-of-natural-antimicrobial-agents-a-safepreservation-approch

Saranraj, P., Alfaris, A. A. S., \& Karunya, K. (2016). Preservation of broiler chicken from food borne microorganisms: a Review. Global Veterinaria, 17(4), 282-294. http://dx.doi.org/10.5829/ idosi. gv.2016.17.04.104113.

Scallan, E., Hoekstra, R. M., Angulo, F. J., Tauxe, R. V., Widdowson, M. A., Roy, S. L., Jones, J. L., \& Griffin, P. M. (2011). Foodborne illness acquired in the United States-major pathogens. Emerging Infectious Diseases, 17(1), 7-15. http://dx.doi.org/10.3201/eid1701. P11101. PMid:21192848.

Scanes, C. G. (2007). Contribution of poultry to quality of life and economic development in the developing world. Poultry Science, 86(11), 2289-2290. http://dx.doi.org/10.3382/ps.2007-86-11-2289. PMid:17954575.

Sebranek, G. J., \& Bacus, J. N. (2007). Cured meat products without direct addition of nitrate or nitrite: what are the issues? Meat Science, 77(1), 136-147. http://dx.doi.org/10.1016/j.meatsci.2007.03.025.

Sebranek, J. G., Lonergan, S. M., King-Brink, M., \& Larson, E. (2001). Meat Science and Processing (3rd ed., p. 141). Zenda, WI: Peerage Press.

Sirocchi, V., Caprioli, G., Cecchini, C., Coman, M. M., Cresci, A., Maggi, F., Papa, F., Ricciutelli, M., Vittori, S., \& Sagratini, G. (2013). Biogenic amines as freshness index of meat wrapped in a new active packaging system formulated with essential oils of Rosmarinus officinalis. International Journal of Food Sciences and Nutrition, 64(8), 921-928. http://dx.doi.org/10.3109/09637486.2013.809706.

Sivropoulou, A., Papanikolaou, E., Nikolaou, C., Kokkini, S., Lanaras, T., \& Arsenakis, M. (1996). Antimicrobial and cytotoxic activities of origanum essebtial oils. Journal of Agricultural and Food Chemistry, 44(5), 1202-1205. http://dx.doi.org/10.1021/jf950540t.

Ultee, A., Bennik, M., \& Moezelaar, H. J. (2002). The phenolic hydroxyl group of carvacrol is essential for action against the food-borne pathogen Bacillus cereus. Applied and Environmental Microbiology, 68(4), 1561-1568. http://dx.doi.org/10.1128/AEM.68.4.15611568.2002. PMid:11916669.

Ultee, A., Gorris, L. G. M., \& Smid, E. J. (1998). Bactericidal activity of carvacrol towards the food-borne pathogen Bacillus cereus. Journal of Applied Microbiology, 85(2), 211-218. http://dx.doi. org/10.1046/j.1365-2672.1998.00467.x.

Ulusoy, B., Hecer, C., Kaynacrca, D., \& Berkan, S. (2018). Effect of oregano essential oil and aqueous oregano infusion application on microbiological properties of Samarella (Tsamarella), a traditional meat product. Food, 7(4), 43. http://dx.doi.org/10.3390/foods7040043.

Xu, J., Zhou, F., Ji, B. P., Pei, R. S., \& Xu, N. (2008). The antibacterial mechanism of carvacrol and thymol against Escherichia coli. Letters in Applied Microbiology, 47(3), 174-179. http://dx.doi.org/10.1111/ j.1472-765X.2008.02407.x.

Yanishlieva, N. V., Marinova, E. M., Gordon, M. H., \& Raneva, V. G. (1999). Antioxidant activity and mechanism of action of thymol and caracrol in two lipid systems. Food Chemistry, 64(1), 59-66. http://dx.doi.org/10.1016/S0308-8146(98)00086-7.

Yemiş, G. P., \& Candogan, K. (2017). Antibacterial activity of soy edible coatings incorporated with thyme and oregano essential oils on beef against pathogenic bacteria. Food Science and Biotechnology, 26(4), 1113-1121. http://dx.doi.org/10.1007/s10068-017-0136-9.

Zhang, H., Wu, J., \& Guo, X. (2016). Effect of antimicrobial and antioxidant activities of spice extract on raw chicken meat quality. Food Science and Human Wellness, 5(1), 39-48. http://dx.doi. org/10.1016/j.fshw.2015.11.003. 